$\boldsymbol{\nabla}$ Artikkeli

\title{
Verkkokeskustelijoiden arviot journalistisesta mediasta demokratiateorioiden valossa
}

\begin{abstract}
Journalistisen median ja demokratian suhdetta käsittelevässä tutkimuksessa kansalaisten mielipiteet mediasta usein sivuutetaan. Tässä artikkelissa pyrin luomaan työkaluja kansalaisten media-arvioiden huomioimiseen jäsentämällä niitä normatiivisten demokratianäkemysten avulla. Muodostan jäsennyksen analysoimalla kahta Ilta-Sanomien internet-sivuilla vuonna 2007 käytyä verkkokeskustelua demokratiateorioiden näkökulmasta. Löydän verkkokeskusteluista kahdeksan median arviointikriteeriä, joilla on vastineensa demokratiateoreettisessa kirjallisuudessa. Keskustelijoiden tapa arvioida mediaa tulee lähelle eliittidemokratiaa ja deliberatiivista demokratiaa, kun taas osallistuvaan demokratianäkemykseen kytkeytyviä arviointikriteereitä käytetään keskusteluissa vähemmän. Tulokset myös täydentävät aiemmassa tutkimuksessa saatua kuvaa suomalaisten media-arvioista.
\end{abstract}

AVAINSANAT: Demokratia, journalismi, kansalaiset, yleisötutkimus, verkkokeskustelut

$\mathrm{K}$ ansalaisilla on usein keskeinen rooli median ja demokratian suhdetta käsittelevissä normatiivisissa teorioissa. Kansalaiset ovat niissä esimerkiksi median välittämän informaation vastaanottajia ja journalismin organisoiman julkisen keskustelun seuraajia tai sen osapuolia. Normatiivisia teorioita sovelletaan empiirisissä tutkimuksissa, joissa journalismia tai mediaa laajemmin arvioidaan demokratiateorioista johdettujen mittatikkujen avulla (esim. Reunanen 2003; Rahkonen 2006; Nieminen ym. 2005).

Vaikka kansalaisille annetaan usein keskeinen rooli normatiivisissa demokratiateorioissa, demokratiateoreettisessa kirjallisuudessa viitataan vain harvoin kansalaisten mediaa kohtaan esittämiin toiveisiin. Esimerkiksi kansalaisten mielipiteitä kansalaisjournalismista ei ole juurikaan tutkittu (Poindexter ym. 2006, 79). Mediaa arvioivassa tutkimuksessakaan ei usein keskustella kansalaisten arvioita empiirisesti tarkastelevan tutkimuksen kanssa (ks. kuitenkin Kivikuru 1996), vaikka jälkimmäistä on Suomessa jonkin verran tehty (esim. Alastalo 1996; Ridell 1998; Haikonen \& Kiljunen 2003).

Demokratiatutkimuksen ja kansalaisten media-arvioita tarkastelevan tutkimuksen keskusteluyhteyden heikkous voi liittyä siihen, että nämä tutkimusperinteet ammentavat eri teorioista ja käyttävät eri käsitteitä. Siinä missä demokratiatutkimus puhuu 
deliberatiivisesta demokratiasta, mediajärjestelmän pluralismista ja journalismin dialogisuudesta, kansalaisten arvioita tarkasteleva tutkimus ankkuroituu ennen kaikkea yleisötutkimuksen perinteeseen, jossa tarkastellaan esimerkiksi kansalaisten mediasuhdetta tai jonkin genren vastaanottoa. Tässä artikkelissa yritän yhdistää näitä tutkimusperinteitä tulkitsemalla kansalaisten media-arvioita demokratiateorioiden käsitteiden avulla.

Ajatukseni on, että kansalaisten media-arvioita voidaan tarkastella demokratiateorioiden näkökulmasta kiinnittämällä huomio siihen, millaisin kriteerein kansalaiset arvioivat mediaa. Analysoin kahta mediakriittistä verkkokeskustelua ja pyrin osoittamaan yhtymäkohtia keskustelijoiden media-arvioinnin ja demokratiateorioiden välillä. Samalla piirtyy kuva siitä, millaisena näihin verkkokeskusteluihin osallistuvat kansalaiset näkevät suomalaisen journalismin 200o-luvun alussa. Näin voidaan lisäksi täydentää aiempaa tutkimusta suomalaisten media-arvioista, jossa verkkokeskusteluja ei ole tietääkseni aiemmin käytetty aineistona.

\section{Kolme näkemystä hyvästä demokratiasta}

Käsitykset median merkityksestä demokratialle riippuvat normatiivisista demokratianäkemyksistä eli näkemyksistä siitä, millaista on hyvä demokratia (esim. Strömbäck 2001, 2005; Baker 2002). Demokratianäkemyksiä on lukuisia (ks. Held 2006), mutta tässä artikkelissa operoin vain kolmella näkemyksellä, jotka ovat eliittidemokratia, osallistuva demokratia ja deliberatiivinen demokratia. Tätä ideaalityyppeihin perustuvaa jaottelua on pidetty toimivana apuvälineenä demokratiaa ja poliittisia instituutioita arvioitaessa (Hanberger 2006, 20; Allern \& Pedersen 2007, 20). Tämän artikkelin kannalta olennaista on, että jaottelua on käytetty median ja demokratian välisen suhteen teoretisoinnissa (Strömbäck 2005; Trappel \& Maniglio 2008). Nämä demokratianäkemykset eroavat toisistaan muun muassa siinä, millaista kansalaisten osallistumista pidetään toivottavana ja millainen rooli julkisella keskustelulla tulisi olla päätöksenteossa.

Eliittidemokratialla tarkoitan näkemystä, jonka mukaan kansalaisten poliittisen osallistumisen tulisi rajoittua vaaleissa äänestämiseen. Poliittisella eliitillä tulisi olla aktiivinen rooli, kun taas kansalaisten tehtäväksi jää reagoida vaaleissa poliittisen eliitin esittämiin vaihtoehtoihin tai heidän toiminnassaan havaittuihin puutteisiin. Näkemyksen mukaan modernien yhteiskuntien ongelmat ovat niin monimutkaisia, että niiden ratkaiseminen edellyttää tavallisten kansalaisten ulottumattomissa olevaa asiantuntijuutta. (Held 2006, 125-157; Strömbäck 2005, 334.) Tällaista näkemystä voidaan kutsua myös minimidemokratiaksi, koska kansalaisilla on siinä minimaalisen pieni rooli (Setälä 2003, 60). Eliittidemokratian näkökulmasta vallankäytön tulisi olla läpinäkyvää, jotta kansalaiset voivat arvioida sitä.

Osallistuvalla demokratialla viittaan näkemyksiin, joiden mukaan kansalaisten tulisi pyrkiä vaikuttamaan poliittiseen päätöksentekoon myös vaalien välillä (vrt. Grönlund 2006, 71). 
Määritelmä on laaja²: Siihen mahtuvat ensinnäkin käsitykset, joiden mukaan kansalaisten tulisi osallistua aktiivisesti nykyisten edustuksellisten instituutioiden puitteissa esimerkiksi osoittamalla mieltään tai pyrkimällä vaikuttamaan kansanedustajien päätöksiin. Lisäksi määritelmään mahtuvat käsitykset, joiden mukaan edustuksellista demokratiaa tulisi täydentää suoran demokratian instituutioilla kuten sitovilla kansanäänestyksillä. Osallistuvassa demokratiassa osallistuminen voi siis merkitä sekä kansalaisten vaikuttamista edustajiinsa ja muihin päättäjiin että kansalaisten mahdollisuuksia päättää suoraan itseään koskevista asioista (vrt. Zittel 2007, 17-18).

Osallistuva demokratia edellyttää, että kansalaiset ovat aktiivisia ja kiinnostuneita vaikuttamaan. Osallistumisen laatu ja määrä määrittävät demokratian toimivuuden: demokratia on tulos kansalaisten toiminnasta ja asenteista (Strömbäck 2005, 336). Kaikki osallistuvan demokratian kannattajat eivät kuitenkaan katso, että kansalaisten aktiivisuus sinänsä riittäisi: tarvitaan myös instituutioita, joiden avulla kansalaisten näkemykset saadaan otettua päätöksenteossa huomioon tai joiden avulla he voivat tehdä sitovia päätöksiä (Setälä 2003, 168).

Deliberatiivisella demokratialla viittaan näkemyksiin, joiden mukaan julkisella harkinnalla pitäisi olla keskeinen rooli poliittisessa päätöksenteossa. Julkisella harkinnalla tarkoitan rationaalista, puolueetonta ja tasa-arvoista keskustelua, johon voivat osallistua ne, joita keskustelun kohteena oleva päätös koskettaa, tai heidän edustajansa. Päätöksenteon ei tulisi perustua eri toimijoiden preferenssien yhteen kokoamiseen (aggregation) vaan niiden muuttumiseen keskustelussa esitettyjen, järkeen vetoavien argumenttien myötä. (Elster 1998, 1, 8.) Tällaisen keskustelun tulisi johtaa konsensukseen eli järkevintä päätöstä koskevaan yhteisymmärrykseen.

Osallistuvan ja deliberatiivisen teorian välistä rajaa ei ole helppo vetää, koska myös deliberatiivisen demokratian teoreetikot pohtivat, miten kansalaisten näkemykset voitaisiin ottaa päätöksenteossa paremmin huomioon. Deliberatiivisessa demokratiassa on kuitenkin kyse demokraattisen osallistumisen laadun parantamisesta määrätynlaisen julkisen harkinnan avulla. Pelkkä osallistumisen lisääminen ei paranna demokratiaa: keskeistä on se, että julkinen keskustelu täyttää sille asetetut vaatimukset. Siten deliberatiivista demokratiaa ei voi pitää pelkästään yhtenä versiona osallistuvasta demokratiasta. (Held 2006, 232, 237.) Maija Setälän $(2006,9)$ mukaan jotkut osallistuvan demokratian kannattajista itse asiassa pitävät deliberatiivista demokratiaa elitistisenä, koska se vähättelee äänestämisen merkitystä ja asettaa keskustelulle vaatimuksia, jotka saattavat suosia korkeasti koulutettuja. Deliberatiivisen demokratian julkiselle harkinnalle asettamia vaatimuksia on kritisoitu myös niin sanotusta radikaalidemokraattisesta näkökulmasta. Esimerkiksi Chantal Mouffe (1999) näkee, että rationaalinen harkinta ei ole koskaan neutraalia vaan siihen kätkeytyy valtasuhteita ja se suosii siten tiettyjä inmisryhmiä. Demokratian toimivuutta ei voi sitoa yhteen keskustelun tyyliin, koska keskustelutyyli kiinnittyy aina johonkin elämänmuotoon marginalisoiden siten muita. Yhteiseen järkeen vetoava konsensus häivyttää ihmisten väliset erot, joita demokratian tulisi päinvastoin vaalia. Mouffen mukaan demokratia edellyttää pikemminkin instituutioita, joiden kautta inmisten erimielisyys tulisi paremmin esiin. 


\section{Median funktiot demokratiassa}

Median ja demokratian suhdetta teoretisoitaessa on perinteisesti pohdittu, millaisia funktioita median tulisi toteuttaa eli mikä on median ideaali rooli demokratiassa. Tässä artikkelissa keskityn perinteisen ammattijournalismin normatiivisiin funktioihin enkä käsittele esimerkiksi viihdemediaa tai sosiaalista mediaa³. Jaan funktiot kolmeen: informointi, vahtikoirana toimiminen ja foorumina toimiminen. Tämä tulee lähelle Kenneth Aspin jaottelua (1994 [Nordenstrengin 1996 mukaan]). Nämä funktiot löytyvät ainakin jossain muodossa myös monista muista jaotteluista (MCNair 1999; Curran 2002, 2005; Graber 2003; Nieminen \& Pantti 2004). Medialla on toki nähty olevan paljon muitakin funktioita, jotka eivät välttämättä mahdu näiden yläkäsitteiden alle, mutta nähdäkseni nämä kolme funktiota muodostavat kuitenkin median funktioiden ytimen, eräänlaisen minimivaatimusten joukon.

Median tulisi informoida kansalaisia, eli tarjota heille sellaista informaatiota, jonka avulla he voivat osallistua poliittiseen toimintaan. Kansalaisten informoimista voidaan pitää kaikille demokratianäkemyksille yhteisenä median funktiona, mutta näkemykset eroavat sen suhteen, millaista informaatiota kansalaisten nähdään tarvitsevan (Strömbäck 2004, 84; Meyer \& Hinchman 2002).

Vahtikoirana toimiessaan median tulisi valvoa kansalaisten puolesta, että heidän valitsemansa edustajat ja muut valtaa pitävät (kuten vahvat taloudelliset [Curran 2002, 219]) tahot toimivat nuhteettomasti ja yleistä etua tavoitellen. Vahtikoirafunktio korostuu erityisesti eliittidemokratiassa, jossa on keskeistä, että poliittinen eliitti ei käytä valtaansa väärin ja että kansalaiset saavat realistisen kuvan sen toiminnasta (Baker 2002). Osallistuvan demokratian kannalta on ongelmallista, jos vahtikoirafunktion liiallinen korostuminen jättää kansalaiset sivustakatsojan rooliin (vrt. Cook 2005, 117-118).

Eliittidemokratian kannalta riittää, että media tarjoaa kansalaisille äänestyspäätöksen kannalta relevanttia informaatiota ja vahtii vallanpitäjiä heidän puolestaan. Osallistuvan ja deliberatiivisen demokratian kannattajat vaativat medialta vielä enemmän (Baker 2002; Meyer \& Hinchman 2002). Median tulisi olla foorumi, jolla käydään julkista keskustelua. Varsinkin deliberatiivinen demokratia edellyttää keskustelua eri näkökulmien välillä: median tulisi organisoida keskustelua, jonka tuloksena syntyvä konsensus on eräänlaista vallanpitäjien vallan kanssa kilpailevaa kommunikatiivista valtaa (vrt. Habermas 1996, 341). Myös osallistuvan demokratian kannalta on tärkeää, että media toimii foorumina, jolla kansalaiset saavat ilmaista mielipiteensä poliittisista kysymyksistä (Strömbäck 2005, 339-340; Ferree ym. 2002, 297).

\section{Aineisto ja menetelmä}

Testaan kahden verkkokeskustelun avulla, miten kansalaisten arvioita voidaan jäsentää demokratiateorioiden näkökulmasta. Kyseessä on siis ensisijaisesti näyteaineisto. Toissijaisena tavoitteena on kuitenkin myös täydentää aineiston avulla aiemman tutkimuksen perusteella muodostunutta kuvaa kansalaisten media-arvioista, koska anonyy- 
meissa keskusteluissa ihmiset saattavat esittää sellaisia mielipiteitä, joita he eivät kasvotusten sanoisi (Ho \& McLeod 2008), ja verkkokeskustelijoiksi saattaa valikoitua erilaisia inmisiä kuin esimerkiksi haastatteluihin, joita on aiemmissa tutkimuksissa usein käytetty aineistoina. Verkkokeskustelijoiden valikoituminen on toki myös aineiston heikkous. Kyse on verkossa aktiivisesti keskustelevista kansalaisista eli vain pienestä osasta suomalaisia (Matikainen 2009, 33). Lisäksi mediaa koskeviin keskusteluihin todennäköisesti osallistuu aiheesta kiinnostuneita ihmisiä, mikä edelleen vähentää tulosten yleistettävyyttä. Yleistettävien tuloksien sijaan pyrin nostamaan verkkokeskustelujen avulla esiin näkemyksiä, joita aiemmin käytetyillä yleisötutkimuksen menetelmillä ei ole välttämättä havaittu.

Tutkimusaineistoksi valitsin Ilta-Sanomien verkkokeskusteluarkistosta kaksi vuonna 2007 käytyä keskustelua (taulukko 1). Molemmissa keskusteluissa puhuttiin suomalaisesta mediasta ja sen suhteesta politiikkaan. Näissä keskusteluissa medialla tarkoitetaan lähinnä ammattijournalismia. Ilta-Sanomien verkkokeskustelut alkavat aina alustuksesta, joka määrittää keskustelun aiheen. Kuka tahansa saa ehdottaa alustuksia, mutta verkkotoimitus päättää, mistä ehdotuksista käynnistetään keskustelu. Keskustelun 1 alustuksessa viitataan presidentti Tarja Halosen ja ulkoministeri Erkki Tuomiojan esittämiin väitteisiin median aseman ylikorostumisesta ulkopoliittisessa keskustelussa. Halosen mukaan olisi syytä tutkia, miten suomalainen media oli käsitellyt Viron niin sanottua pronssisoturikiistaa. Keskustelu ei rajaudu pronssisoturikiistan uutisointiin tai ulkopoliittiseen keskusteluun, vaan median toimintaa ja merkitystä pohditaan laajemmin. Reilun kahden sadan kommentin mittainen keskustelu rönsyilee, ja voisikin puhua yhden keskustelun sijasta muutamasta erillisestä keskustelusta, joista yhdessä puhutaan mediasta, toisessa ulkopolitiikasta ja kolmannessa poliitikoista. Keskustelun loppuvaiheessa siitä muodostuu lähes yksinomaan muutaman aktiivisimman keskustelijan välinen sananvaihto. Keskustelun 2 alustuksen määrittämänä aiheena on ennen kaikkea median alistuva ja passiivinen suhde eliitteihin sekä tutkivan ja kriittisen journalismin puute.

Taulukko 1. Aineiston tunnuspiirteitä.

\begin{tabular}{|l|l|l|}
\hline & Verkkokeskustelu 1 & Verkkokeskustelu 2 \\
\hline Otsikko & $\begin{array}{l}\text { "Onko kriittisellä medialla tilaa } \\
\text { ulkopoliittisessa keskustelussa?" }\end{array}$ & $\begin{array}{l}\text { "Onko media mielestäsi liian } \\
\text { laiskaa?" }\end{array}$ \\
\hline Kommentteja & 215 & 99 \\
\hline Keskustelijoita & 92 & 59 \\
\hline Ajankohta & Toukokuu 2007 & Elokuu 2007 \\
\hline
\end{tabular}


Valitsemani keskustelut ovat siinä mielessä tyypillisiä verkkokeskusteluja, että niissä kohtalaisen pieni joukko keskustelijoita lähettää suuren osan viesteistä (vrt. Pietilä 2001, 20-21). Vaikka keskustelussa on erimielisyyksiä muun muassa median huonon tilan syistä, keskustelijat eivät kuitenkaan jakaudu vastakkaisiin leireihin siten kuin verkkokeskusteluja tutkittaessa on usein havaittu (Pietilä 2001, 30; Mäntymäki 2006). Itse asiassa keskustelijat ovat hyvin samanmielisiä siitä, että median toiminta on puutteellista. Ainoastaan muutama keskustelija kehuu median toimintaa. Erimielisyyttä on kuitenkin siitä, mitä pidetään median toiminnan suurimpina ongelmina. Negatiivinen sävy on yleensäkin tyypillinen poliittisissa verkkokeskusteluissa (ks. Strandberg 2008, 83).

Analyysimenetelmäni rakentuu ajatukselle, että median funktioiden toteutumista voidaan tarkastella arviointikriteerien avulla. Ajatus arviointikriteereistä muistuttaa muun muassa Denis McQuailin (1992) ja Kenneth Aspin (2007) tapaa jakaa median suorituksen arviointi konkreettisiin osa-alueisiin. Esimerkiksi Asp (emt.) pohtii, millaista uutismedian toiminnan tulisi olla, jotta se edistäisi niin sanottua vapaata mielipiteen muodostumista. Hän esittää, että median tulisi tällöin toimia tasapuolisesti, informatiivisesti ja tutkivasti. Edelleen Asp operationalisoi esimerkiksi informatiivisuuden katsomalla, miten relevanttia, tiheää, leveää ja syvää median välittämä informaatio on. Vaikka olen saanut ajatuksen McQuaililta ja Aspilta, en käytä heidän jaottelujaan sellaisinaan. Koska tavoitteenani on osoittaa yhtymäkohtia demokratiateorioiden ja kansalaisten media-arvioiden välillä, käsittelen tässä artikkelissa vain sellaisia arviointikriteerejä, joita esiintyi empiirisessä aineistossa. Arviointikriteereistä muodostuu eräänlainen välittävä mekanismi demokratiateorioiden ja kansalaisten arvioiden välille. Niissä konkretisoituvat eri demokratiateorioiden normatiiviset vaateet median toiminnalle. Näin voidaan luoda yhteys abstraktien demokratiateorioiden ja usein konkreettisemman kansalaispuheen välille. Taustaoletuksena on, että samaan tapaan kuin eri demokratiateorioissa tarkastellaan mediaa eri näkökulmista myös kansalaiset tarttuvat mediaan eri suunnista sitä arvioidessaan.

Käytännössä muodostin arviointikriteerit vertailemalla verkkokeskustelijoiden media-arvioita kirjallisuudessa esiintyviin demokratiateorioihin, tieteellisiin median arviointikriteereihin ja median funktioihin. Kyse oli aineiston ja empirian vuoropuhelusta. Aluksi etsin keskusteluista kaikki kommentit, joissa arvioitiin median toimintaa yleisellä tasolla (jätin huomioimatta esimerkiksi kommentit, joissa arvioitiin vain pronssisoturikiistan uutisointia). Tämän jälkeen tarkastelin keskustelijoiden arvioita ja demokratiateoreettista kirjallisuutta rinnakkain ja yritin löytää niistä yhtymäkohtia. Esimerkiksi yksi keskustelija arvioi mediaa seuraavasti:

Poliittinen journalismi on kuollut. Suomessa on liian yksimielisiä kaikista asioista.--

Tulkitsin, että arvio liittyy median foorumifunktioon ja erityisesti deliberatiivisen demokratian teorioissa esiintyviin ajatuksiin, joiden mukaan julkisessa harkinnassa tulisi tarkastella monipuolisesti erilaisia argumentteja. Kun keskusteluissa esiintyi muitakin samantyyppisiä arvioita, muodostin niitä kuvaavan arviointikriteerin, jonka 
nimesin moniäänisyydeksi. Kokeilin aineistoon muutamia eri luokitteluja ennen kuin muodostin lopullisen luokittelurungon, jonka luokat koostuivat kahdeksasta arviointikriteeristä. Ne olivat 1) median riippumattomuus, 2) aiheiden relevanssi, 3) objektiivisuus, 4) informaation syvyys, 5) kriittisyys, 6) proaktiivisuus, 7) moniäänisyys ja 8) kansalaisläheisyys. Kun olin saanut verkkokeskustelijoiden arviot luokiteltua arviointikriteereittäin, katsoin vielä tarkemmin kunkin kategorian sisällä, millaisia arvioita mediasta esitetään. Yhteenvetona voidaan sanoa, että käytin menetelmänä laadullista sisällönerittelyä, jossa aineiston luokitteluperiaatteet muodostuivat empirian ja teorian vertailun perusteella.

\section{Riippumattomuus - media kytkeytyy valtarakenteisiin}

Ensimmäinen arviointikriteeri on median riippumattomuus vallankäyttäjistä. Se liittyy ensisijaisesti vahtikoirafunktioon: median pitäisi olla riippumatonta niistä tahoista, joiden toimintaa sen tulisi valvoa ja tarpeen tullen kritisoida (McQuail 1992, 120; Strömbäck 2003, 18). Riippumattomuuden arviointi eroaa muista kriteereistä siten, että siinä huomio kiinnittyy enemmän median omistusrakenteisiin tai journalistisiin käytäntöihin kuin median sisältöihin. (McQuail 1992, 99-101.)

Vaikka riippumattomuus on tärkeä kriteeri kaikkien kolmen demokratianäkemyksen kannalta, se painottuu erityisesti vahtikoirafunktiota korostavassa eliittidemokratiassa. Osallistuvan demokratian ja jossain määrin myös deliberatiivisen demokratian kannalta voidaan kuitenkin ajatella, että vaikka median tulee olla riippumaton vallanpitäjistä, sen ei kuitenkin välttämättä tulisi olla täysin riippumaton kansalaisyhteiskunnan toimijoista. Journalistisen median tulisi päinvastoin pohtia, miten se voisi asettua "kansalaisten osallistumisen voimavaraksi" (Heikkilä 2001, 283) tai "yleisönsä julkiseksi resurssiksi entistä enemmän, laajemmin ja intensiivisemmin" (Kunelius 2000a, 201-203).

Median riippumattomuus on arviointikriteerinä 29 verkkokeskustelukommentissa joista muutamassa median vapautta kannatetaan nimenomaan periaatteellisella tasolla. Median vapaus näyttäytyy eräänlaisena perusarvona, jonka merkitystä ei tarvitse erikseen perustella:

On hyvä, että asioista kirjoitettiin ja vaikka lehdistö teki muutaman mitättömän virheen, niin Halonen teki emämunauksen tuomalla ne julkisuuteen. Nyt kaikille meille tuli vain kuva, että hän haluaa kontrolloida lehdistöä ja mediaa ylipäänsä. Se oli harkitsematonta ja kostautuu varmasti Demareille yhä alenevana suosiona! Kukapa meistä nyt haluaisi rajoittaa lehdistön- ja tai medianvapautta?4

(nimimerkki "miss valokuvaukseton")

Riippuvuuden kannalta mediaa arvioivat keskustelijat pitävät muutamaa poikkeusta lukuun ottamatta suomalaista mediaa hyvin riippuvaisena vallanpitäjistä. Osa keskustelijoista sanoo median riippuvuuden johtuvan siitä, että media kytkeytyy rakenteellisesti taloudellisiin ja poliittisiin valtaverkostoihin. Tulkintaa tukee aiempi tutkimus, 
jonka mukaan kansalaiset 1990-luvun loppuun tultaessa mielsivät median osaksi päätöksentekokoneistoa (Aslama ym. 2001, 184).

-- Suomessa media ei ole valtiojohtoa kriittisesti arvioiva sen ulkopuolinen voima, vaan osa pienen maan eliittia. Asiaa ei yhtaan auta se, etta Suomessa on vain yksi valtakunnallinen paivalehti ja sahkoinen media on parin-kolmen toimijan hallussa. -(Prof af Gallsten)

Parissa kommentissa riippuvuuden nähdään johtuvan kasvottomien valtarakenteiden sijasta siitä, että nimenomaan toimittajat samastuvat tai kuuluvat eliittiin:

Media on laiskaa ja samaistuu yläluokkaan. Tosi asia on se, että suurin osa mediasta on porvarillista mm. Alma-Media, Sanoma Oy, Yle jne...syynä on se että toimittajat itse ovat osa tätä yläluokkaa ja on tietysti helpompi samaistua heihin kuin vaikkapa köyhiin tai duunareihin.

Mutta kyllä tuo hallituksen edessä nöyristely on menny liian pitkälle mediassa.Varsinkin Vanhasen "palvonta" tuottaa jo myötähäpeää lukijoissa.

(Oikea yrittäjä)

Siitä, että toimittajien katsotaan kuuluvan eliittiin, on saatu viitteitä aiemmissakin tutkimuksissa: vaaliohjelmien katsojat mielsivät poliitikkojen ja toimittajien olevan samalla puolella, mutta eri puolella kuin katsojat (Jääsaari \& Savinen 1995, 54), ja EVAn (Haikonen \& Kiljunen 2003, 94) kyselyssä ainoastaan vajaa viidennes vastaajista katsoi, että media on "pienen ihmisen puolella vallanpitäjiä vastaan". Toisaalta Maija Kosken (2002) tutkimuksessa haastateltavat kokivat toimittajien päinvastoin olevan tavallisen kansan asialla vallanpitäjiä vastaan.

Keskusteluissa esiintyy myös toisenlainen näkemys median riippumattomuudesta. Siinä ei ole kyse siitä, että media olisi osa valtaeliittiä, vaan media nähdään valtaeliitistä erillisenä mutta sen hyväksikäyttämänä toimijana. Median ja toimittajien koetaan alistuneen eräänlaiseksi vallan välikappaleeksi, jota poliitikot, valtiovalta ja markkinavoimat voivat käyttää hyväkseen:

Mistä lehdet saavat rahansa? Tilaajilta, ilmoittajilta ja pääomasijoittajilta. Ketään näistä ei sovi ärsyttää tai he vievät tilinsä muualle. Siksihän kaikki mediat muistuttavat yhä enemmän toisiaan eikä oikeasti aisan yli potkimista sallita. Ennen Suomen piti olla rähmällään $\mathrm{N}$-liittoon päin, nykyisin tuota tabun luokkaa olevaa koskemattomuutta nauttii eu.

(P. Floyd)

\section{Aiheiden relevanssi - tärkeistä aiheista ei keskustella}

Toinen arviointikriteeri on median käsittelemien aiheiden relevanssi. Informointifunktiota toteuttaakseen median tulisi kertoa asioista, jotka ovat kansalaisille poliittisen 
osallistumisen kannalta olennaisia. Eliittidemokratian näkökulmasta riittää, että media informoi kansalaisia äänestyspäätöksen kannalta olennaisista asioista. Median tulisi esimerkiksi tarjota tietoa siitä, miten yhteiskunta ja poliittinen järjestelmä toimivat, jotta kansalaiset voisivat tämän tiedon perusteella arvioida, miten hyvin kulloinkin vallassa olevat toimijat ovat hoitaneet tehtävänsä (Strömbäck 2005, 339). Osallistuvan demokratian näkökulmasta informaation relevanssi ei määräydy pelkästään vaaliosallistumisen näkökulmasta. Median tulisi informoida kansalaisia myös avoimista ja keskeneräisistä asioista, joihin kansalaiset voivat toiminnallaan vaikuttaa. Mediassa tulisi käsitellä nimenomaan kansalaisten tärkeinä pitämiä aiheita. (Strömbäck 2005, 339-340.) Journalismi voisi toimia käytäntönä, joka nostaa esille esimerkiksi sellaisia inmisten vuorovaikutuksessa esiin tulevia ongelmia ja epäkohtia, joille laitostuneet tietämisen tavat eivät ole riittävän herkkiä (vrt. Kunelius 2001). Käsittääkseni kyse on siitä, että median ei pitäisi valita aiheitaan poliittisen eliitin ehdoilla vaan etsiä aiheita kansalaisten arkielämästä ja sieltä nousevista ongelmista. Myös deliberatiivinen demokratia edellyttää, että media tarjoaa kansalaisille informaatiota, jonka avulla he voisivat osallistua itseään koskevista asioista käytävään keskusteluun tai ainakin pystyisivät sitä seuraamaan. Deliberatiivisen demokratian ihanteena voidaan pitää myös sitä, että mitään aiheita ei ole ennalta suljettu julkisen harkinnan ulkopuolelle (ks. Nieminen 2008).

40 kommentissa arvioidaan mediaa sen perusteella, millaisia aiheita se käsittelee. Nämä keskustelijat vaikuttavat olevan aika yksimielisiä siitä, että median tulisi käsitellä tärkeitä ja olennaisia asioita: sen tulisi keskittyä "oikeisiin ongelmiin" ja "todellisiin epäkohtiin”. Keskustelijat ovat myös lähes yksimielisiä siitä, että suomalainen media ei osaa keskittyä tärkeisiin ja olennaisiin asioihin.

-- Meillähän media jättää kaiken tärkeän kertomatta mutta muistaa kyllä touhottaa jos jonkun poliitikon pöksyt sattuvat olemaan kurtussa. Media on mennyt alaspäin kuin lehmän häntä ja on heti ymmällään jos joku vähänkin edes yrittää arvostella sitä.

(Kaija)

Verkkokeskusteluissa vahvasti esiin nouseva triviaalien ja sensationaalisten aiheiden kritisoiminen on tullut aiemmissakin tutkimuksissa ilmi (Wahl-Jorgensen 2008, 155-156; Couldry ym. 2007, 105-106). Myös EVAn (Haikonen \& Kiljunen 2003, 94) kyselyssä kansalaiset kritisoivat mediaa selvästi vahvimmin juuri siitä, että se korostaa liikaa sensaatioita ja myyvyyttä tärkeiden asioiden kustannuksella. Aihevalintojen kritisoimisen voimakkuus myös aiemmassa tutkimuksessa viittaa siihen, että aiheiden tärkeys on kansalaisille hyvin keskeinen arviointikriteeri (vrt. Nieminen ym. 2005, 9).

Keskustelijat selittävät triviaalien aiheiden korostumista ennen kaikkea median taloudellisilla intresseillä, joita pidetään ensisijaisina suhteessa median muihin intresseihin kuten demokratian edistämiseen. Voimakkaasta kritiikistä huolimatta keskustelijoiden vetoaminen median liiketaloudellisiin periaatteisiin muistuttaa usein Seija Ridellin $(2000,125)$ havaitsemaa ymmärtämispuhetta, jossa nähdään, että media toimii ensisijaisesti kaupallisen logiikan perusteella, eikä tilanne voisi olla muunlainen. 
Taloudellisia rakenteita pidetään siis vastaansanomattomina, luonnonlakien tapaisina faktoina:

-- tuntuu, että tässäkin asiassa pätee vanha kysynnän ja tarjonnan laki. Kyllä mediakonsernit tuottavuuden ja markkinoiden ehdoilla toimivat, joku kyllä vastaa tuloksesta. Siis miksi lähettää toimittajaa tekemään juttua esim. Laatokan seudun ympäristökatastrofista jos kansa ostaa paremmin lehteä, jossa ns. julkkikset poseeraavat uuden rakkaan kanssa.

$--$

(hirvelä-yhtiöt)

Mitkä sitten ovat niitä tärkeitä asioita, jotka media jättää kertomatta? Keskustelijat mainitsevat liian vähälle huomiolle jäävinä aiheina esimerkiksi vero- ja kielipolitiikan, ilmastonmuutoksen, uusliberalismin, demokratiavajeen, EU:n hallintomenojen kasvun ja väestön ikääntymisen. Usein vaikuttaa siltä, että aiheet, joista median tulisi kertoa, ovat vahvasti, usein negatiivisesti arvolatautuneita, ja keskustelijoilla on niistä jo valmis mielipide. Esimerkiksi Paucis Verbis toteaa, että "nykytalouden mielettömyyksiä ja ahneutta voisi ruotia lehtien palstoilla kuten kvartaalitalouden lyhytjännitteistä typeryyttä." Vaihtoehtoisia aiheita ehdottavat keskustelijat vaikuttavatkin usein jo ennalta tietävän, miten asiat ovat, toisin sanoen, mikä on "pielessä". He eivät siis näyttäisi toivovan medialta niinkään itsensä informoimista kuin keskustelua tärkeänä pitämästään aiheesta. Aihevalintojen relevanssi ei siis määrity sen perusteella, mitä pidetään äänestyspäätöksen kannalta relevanttina informaationa, vaan kyse on aiheista, joita keskustelijat pitävät epäkohtina ja joihin he haluaisivat vaikuttaa.

Aiemmasta tutkimuksesta poiketen suurin osa keskustelijoista ei kuitenkaan näytä pitävän ongelmana ainakaan ensisijaisesti sitä, että median aihevalinnat olisivat liian kaukana tavallisen ihmisen arjesta (vrt. Aslama ym. 2001, 185). Pikemminkin keskustelijat toivovat keskustelua juuri sellaisista "yhteiskunnan 'ylätason' kovista teemoista" (Heikkilä 2001, 151), joille mediassa annettua suurta huomiota etenkin kansalaisjournalismin puolestapuhujat ovat kritisoineet. Arkielämään kiinnittyvät aiheet eivät tule juuri esille edes keskustelussa 2, vaikka sen alustuksessa kaivataan "kansalaisten asioihin paneutuvaa journalismia". Poikkeuksena ovat kuitenkin pari kommenttia, joissa tärkeiksi koetut aiheet kytkeytyvät nimenomaan kansalaisten arkielämään. Tällaisia aiheita ovat esimerkiksi työttömyys ja "ihmisten nykyinen velkaantuminen".

\section{Objektiivisuus - puolueellisuus ja piilovaikuttaminen ongelmina}

Median välittämän informaation objektiivisuus ${ }^{5}$ on tärkeä arviointikriteeri kaikkien kolmen demokratianäkemyksen kannalta. Jotta kansalaiset voisivat muodostaa mielipiteensä itsenäisesti ja vapaasti, median tulisi pystyä tarjoamaan heille totuudenmukaista, tarkkaa, tasapuolista ja neutraalia informaatiota (McQuail 1992, 196-236; Asp 2007). Myös laadukkaan keskustelun kriteerinä voidaan pitää sitä, että se pohjautuu faktoihin (Strömbäck 2005, 341). 
Objektiivisuus on arviointikriteerinä 19 kommentissa. Median kritisoiminen objektiivisuusnäkökulmasta ilmenee kahdella tavalla: toisaalta median nähdään tietoisesti poikkeavan objektiivisuuden ihanteesta, ja toisaalta tietojen todenmukaisuuden nähdään kärsivän olosuhteista, kuten toimittajien ammattitaidottomuudesta tai journalismin nopeusihanteesta. Jälkimmäinen tapa puhua objektiivisuudesta esiintyy selvästi harvemmin:

--Tiedontulva on niin suuri ettei oikeellisuudesta aina ole usein väliä. Liikaa sekoilua on havaittavissa kun seuraa eri medioita samoista aiheista.

(Moro-vAAri)

Yleisempiä ovat kommentit, joissa median väitetään valehtelevan, sensuroivan, olevan puolueellinen tai pyrkivän tiedottamisen sijasta vaikuttamaan yleiseen mielipiteeseen:

Pitkään suomalaismedian tehtävänä oli uutisoida vastuuntuntoisesti YYA-kumppanistamme. Valehtelu ja puolitotuudet jättivät jälkensä toimintatapoihin.

Ruotsissa journalistit ovat suurimmaksi osaksi vasemmistolaisia, tilanne voi olla samankaltainen myös Suomessa.

(Pekka, Kaakkois-Suomesta)

Se, että keskustelijat näkevät median ohjaavan totuutta tiettyyn suuntaan, kertovan puolitotuuksia tai antavan jopa virheellisiä tietoja, herättää kysymyksen, miten keskustelijat ovat saaneet tietoonsa sen "totuuden", johon he uutisointia vertaavat (vrt. Wahl-Jorgensen 2008, 157). Yleisöllähän ei pitäisi olla käytännössä juurikaan mahdollisuutta arvioida uutisoinnin todenmukaisuutta (Ridell 1998, 292), vaikka internetin myötä tämän asetelman voidaan katsoa jossain määrin muuttuneen. Oletan, että kyse voi olla kulttuurisista, ulkoa opituista käsityksistä (vrt. Alastalo 1996). Esimerkiksi käsitykset lehtien sitoumuksista jatkavat omaa, itsenäistä elämäänsä sen jälkeen, kun poliittisista sitoumuksista on ainakin virallisesti sanouduttu irti. Tutkimuksissa on osoitettu että poliittiset sitoumukset elävät edelleen sekä sanomalehtien tilaajien että ei-tilaajien mielissä. (Kärki 2004, 149-152; Hujanen 2007, 172.) ${ }^{6}$ Tämä tulee esille myös verkkokeskusteluissa:

Niin, totuutta ikäänkuin ohjataan "oikeaan" suuntaan, minne media ja sen kannattama puolue haluaakin.

Tämähän on ollut tunnetusti jo vuosia "maan tapa", kuten asia ilmaistaan poliittisessa kielenkäytössä.

(Ramiro)

Toisaalta objektiivisuuskritiikki saattaa juontua myös median sisältöjen havainnoinnin subjektiivisuudesta. Tutkimusten mukaan varsinkin ne, joilla on vahvoja poliittisia mielipiteitä, ovat taipuvaisia näkemään median olevan kallellaan vastusta- 
jien leiriin päin. Ihmiset saattavat pitää värittyneenä sellaista informaatiota, joka ei vastaa heidän ennalta muodostamiaan mielipiteitä. (Schmitt ym. 2004; Gunther \& Liebhart 2006.)

\section{Informaation syvyys - ihanteena analyyttinen journalismi}

Yksi verkkokeskustelijoille ja demokratiateoretisoinnille yhteinen arviointikriteeri on myös median välittämän informaation syvyys? ${ }^{7}$. Informointifunktion kannalta kyse on siitä, että median pitäisi raa'an informaation välittämisen lisäksi kertoa kansalaisille syistä, seurauksista ja yhteyksistä asioiden välillä (Murdock 2005, 216). Osallistuvan demokratian näkökulmasta median tulisi luoda yhteyksiä kansalaisten elämänpiirin ja poliittisen koneiston toiminnan välille. Median ei myöskään tulisi ainoastaan kuvailla yhteiskunnallisia ongelmia vaan kertoa, miten niitä voitaisiin ratkaista. (Strömbäck 2005, 340.) Foorumifunktion kannalta vaatimus keskustelun syvyydestä juontuu varsinkin deliberatiivisen demokratianäkemyksen ihanteesta, jonka mukaan keskustelun lopputuloksen tulee määräytyä argumenttien pätevyyden pohjalta (Nieminen 2008, 20-21). Tällöin median toimintaa voidaan arvioida esimerkiksi sen perusteella, miten hyvin se pystyy tietyn kiistakysymyksen yhteydessä tuomaan esiin ne perusteet ja näkökohdat, jotka puhuvat eri kantojen puolesta ja niitä vastaan (Asp 2007, 34-35). On myös esitetty, että pelkkä argumenttien kirjaaminen ei riitä, vaan median tulisi aktiivisesti etsiä, testata ja koetella niitä (Reunanen 2003; Ettema 2007, 145). Eliittidemokratian näkökulmasta informaation syvyys ei ole välttämättä yhtä tavoiteltavaa. Yksinkertaistetun ja kärjistetyn informaation voidaan nimittäin ajatella olevan taloudellisinta kansalaisille, joilla ei ole aikaa, kykyä tai motivaatiota käsitellä syvällistä informaatiota yhteiskunnan eri osa-alueilta (Zaller 2003).

12 kommentissa toivotaan, että mediassa puhuttaisiin asioista nykyistä syvällisemmin. Näissä kommenteissa toivotaan lisää analyyttista, "syvälle käypää" uutisointia ja keskustelua. Median pitäisi pohtia asioiden syitä ja seurauksia, eri toimijoiden motiiveja ja kyseenalaistaa esimerkiksi "kehitysaputoiminnan periaatteet".

Nykyinen uutisointi on melkeempä pelkkää viihdettä. Jostain akuuteista tapahtumista uutisoidaan että nyt kuoli ihmisiä $128 \mathrm{kpl}$ onnettomuudessa jne jne. Mutta siihen se jää.

Toivoisin tutkivaa ja syihin keskittyvää journalismia enemmän. Analyyttistä keskustelua ja vähemmän henkistä saastetta kuten uutisia "julkkiksista". --

(K3lmu)

Toive informaation syvyydestä on tullut esiin myös aiemmassa tutkimuksessa. Yhdysvaltalaisessa tutkimuksessa mediaan kriittisesti suhtautuneet kansalaiset toivoivat poliittiselta uutisoinnilta syvyyttä eli esimerkiksi asioiden historiallisen taustan avaamista (Cappella \& Jamieson 1997, 221). Tanskalaisessa tutkimuksessa erityisesti korkeasti koulutetut haastateltavat toivoivat median välittämältä informaatiolta uutisten taustoittamista ja kontekstoimista (Schrøder \& Phillips 2007, 896-897). 
Sen sijaan verkkokeskusteluissa ei esiintynyt aiemmassa tutkimuksessa esiin tullutta näkemystä, jonka mukaan median tulisi kertoa asioista yksinkertaisemmin, tavallisen kansan kielellä (vrt. Alastalo 1996). Tämä liittynee osittain siihen, että monet keskustelijoista näyttävät asettuvan tällaisen "tavallisen kansan" yläpuolelle.

\section{Kriittisyys - vahtikoira ei hauku tarpeeksi}

Yhtenä vahtikoirafunktion arviointikriteerinä voidaan pitää median kriittisyyttä vallanpitäjiä kohtaan. Pelkkä vallanpitäjien toiminnan dokumentointi ei vahtikoirafunktion kannalta riitä: toimittajien tulisi kritisoida ja kommentoida poliittisten toimijoiden tarjoamaa lähdemateriaalia eikä vain neutraalisti välittää sitä (Norris 2000, 29). Median pitäisi siis kyseenalaistaa tai kritisoida vallanpitäjien toimintaa ja puhetta. Kriittisyys vallanpitäjiä kohtaan painottuu erityisesti eliittidemokratiassa, jossa on tärkeää kansalaisten mahdollisuus arvioida realistisesti vallanpitäjien toimintaa. Osallistuvan demokratian kannalta toimittajien liiallinen kriittisyys vallanpitäjiä kohtaan voi olla ongelma, jos kansalaiset jäävät tällöin sivustakatsojiksi.

Mediaa arvioidaan kriittisyyden kannalta 38 kommentissa, joista suurimmassa osassa todetaan, että suomalainen media ei ole riittävän kriittinen vallanpitäjiä ja erityisesti poliitikkoja kohtaan. Vallanpitäjien kritisointia pidetään median tärkeänä tavoitteena, eikä kukaan keskustelija kyseenalaista sitä periaatteellisella tasolla. Se, että kriittisyyden vaatimus tulee voimakkaasti esille, voi johtua keskustelun aiheesta: keskustelun 1 otsikkohan on "Onko kriittisellä medialla sijaa ulkopoliittisessa keskustelussa?" Mutta koska kriittisyyden vaade esiintyy tiheästi myös keskustelussa 2, keskustelun 1 aihe ei yksin selitä tämän arviointikriteerin painoarvoa.

Kriittisyyden puute yleistetään usein koskemaan kategorisesti koko suomalaista mediaa. Keskustelijoiden käsitykset median kritiikittömyydestä muistuttavat niiden tutkijoiden käsitystä, joiden mukaan suomalainen media on perinteisesti kritisoinut vallanpitäjiä kovin vähän, vaikka sananvapauden muodolliset edellytykset ovat kunnossa (Pulkkinen 1996; Moring 2008). Aiemmasta tutkimuksesta (Koski 2002, 314315) poiketen suurin osa keskustelijoista ei näe kriittisyyden lisääntyneen, vaan kriittisyyden puute näyttäytyy median pysyvänä ominaisuutena. Poikkeuksena ovat pari keskustelijaa, jotka näkevät kriittisyyden lisääntyneen. Esimerkiksi Hupsista kirjoittaa:

Totta, mediaahan on arvosteltu valtion johdon myötäilemisestä, siinä mielessä Halosen ja Tuomiojan kritiikki ihmetyttääkin että se esitettiin ajankohtana, jona media on ollut kriittisempi.

Kiinnostavaa on, että kriittisyyden puute näyttäytyy ennen kaikkea suomalaisen median ominaisuutena, eräänlaisena kansallispiirteenä, jota selitetään muun muassa poliittisella historialla. Muutamassa kommentissa suomalaisen media kritiikittömyyttä verrataankin ulkomaiseen mediaan: 
-- Minusta suurin puute Suomen mediassa on se, ettei ole tasokasta aikakausijulkaisua, vaikkapa sellaista kuin TIME tai STERN. Näissä lehdissähän on annettu tilaa myös yleisen poliittisen mielipiteen vastaisille artikkeleille. TIME:ssa Bushkin on saanut oikein isän kädestä.

(stara)

Monet keskustelijat vaativat medialta kriittisyyttä nimenomaan poliittisia vallankäyttäjiä vastaan: vaatimus markkinavoimien kritisoinnista tulee selvästi harvemmin esiin. Englantilaisessa tutkimuksessa havaittiin, että poliitikkoja epäluotettavina pitäneet kansalaiset arvostivat korkealle median roolia vallan vahtikoirana (Hargreaves \& Thomas 2002, 61). Saattaakin olla, että verkkokeskustelijoiden toive kriittisyyden lisäämisestä ainakin osittain juontuu heidän tyytymättömyydestään Suomen poliittisen järjestelmän instituutioita tai sen toimijoita kohtaan. Tällöin media näyttäytyisi kenties eräänlaisena potentiaalisena muutosvoimana, joka kasvaneeksi koetun valtansa (Karppinen ym. 2010, 18-19; Ruostetsaari 2003, 366) avulla voisi olla "-- ase tai väline, jolla on edes jotenkin mahdollisuus seurata ja joskus jopa ohjata vallankäyttäjiä"(Katariina). Median kriittisyyttä ei siten välttämättä toivota niinkään siksi, että se on demokraattisen julkisuuden arvo sinänsä vaan pikemminkin siksi, että sen avulla voitaisiin vaikuttaa koettuihin epäkohtiin.

Usein kommenteista ei selviä, mitä keskustelijat oikeastaan tarkoittavat kriittisyydellä, ja siksi vaatimus sen lisäämisestä jääkin aika abstraktiksi (vrt. Kunelius 200ob, 100). Muutamassa kommentissa termin sisältöä kuitenkin avataan tarkemmin. Ainakin se näyttää liittyvän riippuvuuteen: ongelmana pidetään sitä, että vallanpitäjiä myötäillään, heidän sanomisiaan toistellaan totuuksina niitä kyseenalaistamatta. Kriittisyyden voidaan nähdä tarkoittavan myös sitä, että "poliittisen eliitin tekemisien tai mikä tärkeämpää heidän tekemättömyyksiensä perään voidaan kysellä" (Funlandian kansalainen). Muutamassa kommentissa tulee esiin, että kriittisyyden ei pitäisi merkitä epä-älyllistä haukkumista, vaan valtaapitävät pitäisi haastaa "tiedon keinoin" (Qwer) ja kritiikin pitäisi kohdistua tärkeisiin asioihin, eikä työn kannalta triviaaleihin seikkoihin, kuten ulkonäköön tai yksityiselämään. Myös aiemmissa tutkimuksissa on havaittu eron tekeminen epäasiallisen ja asiallisen kriittisyyden välille (Koski 2002, 306). Selvää on, että millainen tahansa vallanpitäjien kritikointi ei kelpaa, vaan kritiikin tulisi olla perusteltua ja kohdistua olennaisiin asioihin.

Kriittisyyden puutetta selitetään muun muassa toimittajien älyn puutteella, laiskuudella tai pelkuruudella. Toimittajat nähdään lähinnä passiivisena laumana, joka ei uskalla haastaa vallanpitäjiä. Toisaalta muutamia älynsä tai asenteensa vuoksi lauman yläpuolelle nousevia toimittajia ihaillaan paikoin varauksettomasti. Tällaisina poikkeuksellisen kriittisinä toimittajina keskustelijat pitävät Hannu Karpoa, Susanna Päivärintaa ja Petri Sarvamaata. Esimerkiksi P.Floyd kirjoittaa seuraavasti:

-- Että minä ihailin tätä Päivärintaa. Paitsi, että on kaunis nainen niin on todella veitsenterävä äly ja piinkova toimittajan moraali. Eipä ihme, ettei olekaan näkynyt kuvissa ja tunnelmissa viime aikoina. -- 


\section{Proaktiivisuus - tutkivan journalismin kaipuu}

Vahtikoirafunktio edellyttää medialta myös proaktiivisuutta. Tässä arviointikriteerissä on kyse siitä, missä määrin media oma-aloitteisesti tutkii vallanpitäjien toimintaa. Kyse on ennen kaikkea tutkivasta journalismia, joka tuo päivänvaloon kätkettyjä ongelmia, kuten korruptiota tai petoksia (Bennett \& Serrin 2005). Proaktiivisuutta voidaan pitää ennen kaikkea eliittidemokratialle tärkeänä arviointikriteerinä.

13 keskustelukommentissa peräänkuulutetaan tutkivaa journalismia. Sitä ei nähdä Suomessa muutamaa poikkeusta (esimerkiksi Suomen Kuvalehteä, muutamaa nimeltä mainittua toimittajaa) lukuun ottamatta juurikaan olevan:

Minne unohtui tutkiva journalismi?

Vielä 80-luvulla lehdistömme tonki ja selvitti sellaisiakin asioita, jotka tärkeytensä vuoksi johtivat myöhemmin jopa lakialoitteisiin ja yhteiskunnallisiin muutoksiin (esim. rötösherrajahti, kotiryssäjärjestelmä, idänkaupan kaksoislaskutus jne). Miksi samanlaista keskustelunherättämistä ei tapahdu enään nykyään?

Hyvä tutkiva journalismi toimii yhteiskunnallisen keskustelun herättäjänä ja demokratian vahtikoirana. Nukkuva journalisti on jokaisen rötösherran toiveiden mukainen journalisti.

(Tsaudi64)

Keskustelijoiden mielestä median ei pitäisi jättäytyä tiedotteiden ynnä muiden sellaisten varaan vaan pyrkiä aktiivisesti "kaivelemaan ja tonkimaan" asioita. Tutkivaa journalismia toivovat keskustelijat tuntuvat lähtökohtaisesti olettavan, että jos media tutkisi vallanpitäjien toimintaa pintaa syvemmältä, toiminnassa havaittaisiin puutteita. Siten tutkivan journalismin kaipuunkin voidaan olettaa juontuvan tyytymättömyydestä tai kyynisyydestä poliittisia toimijoita kohtaan.

\section{Moniäänisyys - yhden totuuden maa}

Journalismin moniäänisyys on foorumifunktion kannalta olennainen arviointikriteeri. Tarkoitan moniäänisyydellä mediassa esiintyvien näkökulmien tai toimijoiden monimuotoisuutta (diversity ${ }^{8}$ ). Ensinnäkin voidaan arvioida, kuka pääsee uutisdiskurssiin (ks. esim. Bennett ym. 2004, 438), jolloin journalismin arviointikriteeri on "siinä esiintyvien toimijoiden kirjo" (Heikkilä \& Kunelius 1997, 7). Toisenlaisen näkökulman mukaan olennaista ei ole niinkään se, että kaikki pääsevät puhumaan, vaan se, että mahdollisimman monet eri näkökohdat tulisivat keskustelussa esiin (Glasser \& Craft 1997, 31). Tätä voidaan pitää deliberatiivisen demokratian kannalta tärkeänä näkökulmana, sillä ihanteen mukaisessa julkisessa harkinnassa olennaisinta ovat argumentit, eivät niiden esittäjät (Ferree ym. 2002, 302; vrt. Nieminen 2008, 20-21).

Mediaa tarkastellaan moniäänisyyden näkökulmasta 19 kommentissa. Suomalaisen median nähdään antavan vain yhden näkökulman kuhunkin asiaan: Media on "yksi- 
puolinen" ja "yksisilmäinen" ja mediassa on vain "yksi totuus". Vaihtoehtoisille mielipiteille, toisinajattelulle ja "yleisen poliittisen mielipiteen vastaisille artikkeleille" ei ole tilaa.

Toiset pitävät yksiäänisyyttä nimenomaan suomalaisen median perinteisenä ongelmana, kun taas osa pitää sitä seurauksena median muutoksesta:

Poliittinen journalismi on kuollut. Suomessa ollaan liian yksimielisiä kaikista asioista. Samoin galluppeja tehdään ja ohjaillaan koko ajan poliittista päätöksentekoa, jotta äänestäjät äänestäisivät niitä, jotka pärjäävät gallupeissa.

(metsuri)

Suomalaismedia on yhtä yksisilmäinen tänään kuin 70-luvullakin. Kolme vuosikymmentä sitten se toisti virallista mantraa ala" "näin Neuvostoliitossa". Tänään se toistaa yksipuolista mantraa "ilmastonmuutoksesta". Molemmissa tapauksissa se kiroaa toisinajattelijat ja lutkuttaa virallisen totuuden julistajia.

(Heikki)

\section{Kansalaisläheisyys - onko tavallisen kansalaisen mielipide tärkeä?}

Kansalaisläheisyyden kriteerin avulla voidaan arvioida, missä määrin yksittäiset kansalaiset ja kansalaisryhmät saavat puhua mediassa omalla äänellään. Eliittidemokratian näkökulmasta riittää, että vallasta kilpailevien eliittien näkemykset tulevat mediassa tarpeeksi laajasti esiin, joten kansalaisläheisyys ei ole tärkeää. Sen sijaan osallistuvan demokratian kannalta median kansalaisläheisyys on erittäin tärkeä arviointikriteeri (Ferree ym. 2002, 297). Deliberatiivisen demokratian näkökulmasta kansalaisläheisyyttä ei ole aivan yhtä tärkeä kriteeri: olennaista ei ole se, ketkä pääsevät ääneen vaan se, että monenlaiset näkökulmat pääsevät julkisuuteen.

Mediaa arvioidaan verkkokeskusteluissa kansalaisläheisyyden näkökulmasta 7 kommentissa:

-- Niin Ylessä kuin muuallakin mediassa, on unohdettu "taviskansalainen" vain elinkeinoelämän edustajat, ns.tutkijat ja politiikot saavat sanomansa perille, niitä toistellaan totuuksina. --

(näin)

Koska vain muutama keskustelija arvioi mediaa kansalaisläheisyyden kannalta, kansalaisläheisyys ei vaikuttaisi olevan kovinkaan tärkeä arviointikriteeri. Tässä on ero joihinkin aiempiin tutkimuksiin, joissa noin puolet vastaajista tai haastateltavista oli sitä mieltä, että mediassa esitetään liian vähän tavallisia inmisiä (Alastalo 1996, 383; Hargreaves \& Thomas 2002, 77). Havainto kansalaisläheisyyden pienestä painoarvosta verkkokeskusteluissa perustuu myös siihen tapaan, jolla muut keskustelijat reagoivat kansalaisten näkökulmaa peräänkuuluttaviin puheenvuoroihin: Kukaan ei yhdy kansa- 
laisten näkökulmia lisää toivoviin kommentteihin ja muutama keskustelija itse asiassa kyseenalaistaa kansalaismielipiteen arvon.

Minä en myös usko ns. kadunmiehen viisauteen päättää tärkeistä asioista. Sitä varten on koulutetut ja osaavat asiantuntijat. On populismia väittää että "kansa tietää". Esimerkkinä joku ydinvoima/natokeskustelu. --

(MichaelB)

\section{Yhteenveto}

Verkkokeskustelijat arvioivat median riippumattomuutta, aiheiden relevanssia, objektiivisuutta, syvällisyyttä, kriittisyyttä, proaktiivisuutta, moniäänisyyttä ja kansalaisläheisyyttä. Arviot painottuivat keskusteluissa eri tavalla ja saivat erilaisia sisältöjä. Siksi voidaan tarkastella, miten lähelle kutakin kolmea demokratianäkemystä keskustelijoiden käyttämät arviointikriteerit asettuvat.

Eliittidemokratiassa korostuvat vahtikoirafunktiolle keskeiset arviointikriteerit. Median tulisi olla itsenäinen ja kriittinen vallanpitäjiä kohtaan, jotta kansalaiset saisivat realistisen kuvan siitä, miten heidän valitsemansa edustajat toimivat. Siksi on myös tärkeää, että median välittämä tieto on mahdollisimman objektiivista. Sen sijaan median kansalaisläheisyys ja informaation syvyys voidaan nähdä jopa demokratian toimivuutta haittaavina tekijöinä. Verkkokeskusteluissa tulivat vahvasti esille eliittidemokratiaan kytkeytyvän vahtikoiranfunktion kannalta keskeiset arviointikriteerit eli riippumattomuus, kriittisyys ja proaktiivisuus. Keskustelua sävytti monin paikoin epäluottamus poliittista eliittiä kohtaan, ja media koettiin eräänlaisena aseena, jolla omaa etuaan tavoitteleva eliitti voitaisiin saada kuriin. Median kuulumista eliittiin kritisoitiin, mutta median tulisi haastaa vallanpitäjät älyllä ja asiantuntijatiedolla, ei kansan syvien rivien tuntoja esiin nostamalla. Ihanteellista toimittajaa pidettiin enemmän kansaa edustavana vallanpitäjien kanssa peistä taittavana sankarina kuin kansalaisen pariin laskeutuvana, heidän arkielämästään aiheita etsivänä tai mielipiteitään aktiivisesti esille tuovana "kanssaihmisenä". Mediajulkisuuden eliittikeskeisyyttä sinänsä ei myöskään juuri kritisoitu, vaan ongelmana pidettiin pikemminkin sitä, että media on liian riippuvainen niistä eliiteistä, joiden toimintaa sen tulisi tarkastella. Vahtikoirafunktion korostuminen voi osittain johtua keskustelujen aiheista. Kytkeytyiväthän ne vahvasti juuri median ja vallanpitäjien välisiin suhteisiin.

Osallistuvassa demokratiassa olennaista on kansalaisten mielipiteiden esille tuominen mediassa ja osallistumisen kannalta relevantin, kansalaisten arkielämään kytkeytyvän tiedon tarjoaminen. Vain muutamassa verkkokeskustelukommentissa toivottiin tavallisten kansalaisten näkökulmien esiin nostamista tai arkielämän kannalta relevanttien aiheiden lisäämistä. Toisaalta keskustelijat näyttävät toivovan, että mediassa käsiteltäisiin aiheita, joita he itse pitävät tärkeinä, ja he tuntuvat uskovan, että näin voitaisiin vaikuttaa myös poliittisiin päätöksiin. Tässä keskustelijat asettuvat lähemmäs osallistuvaa demokratiaa kuin eliittidemokratiaa: vaikka niin sanotun tavallisen 
kansan ääntä ei haluttaisikaan kuulla mediassa nykyistä enempää, keskustelijat haluaisivat kuitenkin omien poliittisten kantojensa tulevan mediassa nykyistä paremmin esille. Näin median toivotaan toimivan kanavana, jonka välityksellä kansalaisten ääni vaikuttaisi poliittisiin päättäjiin myös vaalien välillä.

Deliberatiivisen demokratian näkökulmasta keskeistä on informaation ja keskustelun syvyys. Moniäänisyys on kansalaisläheisyyttä tärkeämpää: olennaista ei ole se, kuka pääsee puhumaan, vaan se, miten puhutaan. Verkkokeskusteluissa tuli esille kantoja, jotka asettuvat lähelle deliberatiivista demokratianäkemystä. Keskustelijat toivoivat mediassa käydyltä keskustelulta moniäänisyyttä, rationaalisuutta ja syvällisyyttä. Myös tanskalaisessa tutkimuksessa havaittiin, että kansalaiset toivoivat julkiselta keskustelulta näitä ominaisuuksia (Schrøder \& Phillips 2005, 194). Vertailu Tanskaan tuo esille myös kiinnostavan eron: Tanskalaiset kannattivat myös deliberatiivisen demokratian ihannetta siitä, että keskustelun tuloksena muodostuisi totuus tai jonkinlainen yleistä etua koskeva konsensus (emt.). Analysoimissani verkkokeskusteluissa tällaista ihannetta ei tullut ilmi, vaan nimenomaan konsensusta ja yksimielisyyttä kritisoitiin. Suomalaisessa poliittisessa kulttuurissa konsensus saa toki hyvin erilaisen merkityksen kuin deliberatiivisessa demokratianäkemyksessä. Joka tapauksessa verkkokeskustelijat näyttäisivät haluavan, että media repisi auki suomalaisen konsensuksen ja paljastaisi sen taakse kätkeytyvät yhteiskunnalliset ristiriidat. Tässä suhteessa keskustelijoiden ajatukset muistuttavatkin radikaalidemokraattista näkemystä, jonka mukaan intressikonflikteja ei tulisi pyrkiä häivyttämään vaan poliittisten kantojen perustavanlaatuista vastakkaisuutta ja sovittamattomuutta tulisi päinvastoin vaalia. Toisaalta joidenkin keskustelijoiden näkemykset asettuvat kauas radikaalidemokratiasta siinä, että he arvostavat nimenomaan analyyttista keskustelua ja vallanpitäjien haastamista tiedon keinoin. He siis asettavat ihanteelliselle keskustelulle tiettyjä normeja.

Yhteenvetona voidaan todeta, että moni verkkokeskusteluissa esiin tullut mediaarvio asettuu lähelle eliittidemokratiaa, koska niissä korostetaan vallanpitäjien vahtimista. Lisäksi eliittikeskeisen julkisuuden tilalle ei muutamaa poikkeusta lukuun ottamatta haluta kansalaisia lähempänä olevaa journalismia. Toisaalta keskustelijoiden arvioissa näkyy myös eliittidemokratian vaatimukset ylittävä foorumifunktio. Tällöin keskeisenä pidetään kuitenkin foorumin moniäänisyyttä ja keskustelun syvällisyyttä, ei niinkään kansalaisläheisyyttä. Tässä suhteessa mediaa arvioivat kommentit asettuvat lähemmäs deliberatiivista kuin osallistuvaa demokratiaa.

Olen edellä pyrkinyt osoittamaan, että kansalaisten arvioita journalistisesta mediasta voidaan tarkastella demokratiateorioiden näkökulmasta. Empiirinen analyysi paljasti, että kansalaiset tarkastelevat mediaa eri näkökulmista ja heillä on sen suhteen erilaisia odotuksia, joissa voidaan havaita tiettyjä yhtymäkohtia normatiivisiin demokratianäkemyksiin. Jatkossa arviointikriteereitä olisi kuitenkin tarkennettava ja täydennettävä käyttämällä laajempia ja paremmin yleistettävissä olevia aineistoja. Myös kansalaisten arvioinnin suhdetta demokratiateorioihin tulisi täsmentää.

Aineiston analyysin sivutuotteena syntyi muutamia aiemmasta tutkimuksesta kiinnostavalla tavalla poikkeavia havaintoja kansalaisten media-arvioista. Tavallisten kansalaisten esiin tuomista, arkielämän kannalta relevanttien aiheiden lisäämistä ja kan- 
san kielellä uutisointia ei juurikaan pidetty tärkeinä tavoitteina, toisin kuin aiemmassa tutkimuksessa on havaittu (vrt. Alastalo 1996, 383; Aslama ym. 2001, 185; Hargreaves \& Thomas 2002, 77; Hujanen 2007). Havaintoa voidaan ymmärtää tarkastelemalla tutkimustuloksia niin sanotun häivedemokratian (stealth democracy) kannatuksesta. John Hibbingin ja Elizabeth Theiss-Morsen (2002) kiistellyn havainnon mukaan osa yhdysvaltalaisista ei pidä eliittivetoista päätöksentekotapaa sinänsä huonona vaan lähinnä epäilee eliittien motiiveja. Samansuuntainen tutkimustulos on saatu myös Suomessa (Bengtsson \& Mattila 2009). Verkkokeskustelijoiden mediaan kohdistuvissa odotuksissa voi olla kyse samankaltaisesta ajattelusta, jossa ongelmana ei pidetä niinkään journalismin "edustuksellista logiikkaa" (Heikkilä 2001) tai "institutionaalista orientoitumista" (Ruoho \& Torkkola 2010, 117-127) sinänsä vaan pikemminkin median kyvyttömyyttä tai haluttomuutta toteuttaa sen perinteisiä ideaaleja. Keskustelijoiden näkemykset asettuvat kiinnostavalla tavalla vastakkain myös sen journalismissa vahvistuvan trendin kanssa, jossa kansalaisten arjesta nousevia aiheita ja tavallisten ihmisten näkemyksiä tuodaan entistä vahvemmin esille (esim. Hujanen 2009). Todennäköisesti monet keskustelijoista eivät ainakaan varauksettomasti kannattaisi esimerkiksi kansalaisjournalismin osallistavien käytäntöjen vakiinnuttamista osaksi valtamedian keinovalikoimaa.

Ero aiempaan tutkimukseen voi johtua aineistosta. Tässä artikkelissa tarkastellut verkkokeskustelijat saattavat olla kovin erilainen joukko inmisiä kuin ne, joiden mielipiteitä on aiemmin selvitetty erilaisin haastattelumenetelmin. On esimerkiksi havaittu, että verkossa politiikasta keskustelevat kansalaiset ovat keskimääräistä kiinnostuneempia politiikasta (Strandberg 2008, 81). Myös analysoiduissa keskusteluissa tuli esiin voimakkaita poliittisia kantoja. Lisäksi verkkokeskustelijoiden ankara mediakriittisyys on kovin marginaalista, sillä valtaosa suomalaisista on tyytyväisiä uutismediaan ja moniin sen toiminnan osa-alueisiin (Karppinen ym. 2010). Toisaalta voi olla niinkin, että anonyymeissa verkkokeskusteluissa mediakriittisyys saa enemmän elintilaa ja hyväksyntää kuin esimerkiksi ryhmähaastatteluissa, joissa ryhmäpaine saattaa vaimentaa mediakriittisiä äänenpainoja (vrt. Ridell 1998). Joka tapauksessa jatkossa olisi kiinnostavaa tutkia laajempien aineistojen avulla, millaisia eroja median kansalaisarvioinnissa on. 


\section{Viitteet}

1 Strömbäck tosin käyttää lisäksi myös neljättä demokratianäkemystä, proseduraalista demokratiaa.

2 Suppeammin käsitteen määrittelee esimerkiksi Held (2006, 209), joka viittaa sillä 1970-luvulla syntyneeseen vasemmistolaiseen liikkeeseen.

3 Käytän kuitenkin lyhyttä ja ytimekästä mediaa ammattijournalismin synonyymina.

4 Olen lihavoinut kommenteista kohtia, joihin tulkintani erityisesti perustuu.

5 Käytän objektiivisuutta yleisenä terminä enkä ota tarkemmin kantaa käsitteen ympärillä käytyyn tieteelliseen keskusteluun (ks. esim. Hemánus \& Tervonen 1980).

6 Toisaalta tutkimus on osoittanut sitoumusten edelleen myös näkyvän lehtien sivuilla (Holmberg 2004).

7 Termi (information depth) on lainattu Aspilta (2007, 35), mutta määrittelen sen laaja-alaisemmin kuin hän.

8 Rajaan käsitteen tässä näkökulmien ja journalismin sisällöissä esiintyvien toimijoiden monimuotoisuuteen, jolloin ulkopuolelle jäävät esimerkiksi omistuksen, työvoiman ja ohjelmatyyppien monimuotoisuus (ks. Napoli 1999, 10), vaikka niilläkin voi toki olla vaikutusta siihen, miten moniäänisiä sisällöt ovat.

\section{Kirjallisuus}

Alastalo, Marja (1996). "Kyllähän siitä hirveesti voidaan kirjoittaa, mutta..." Kunnon kansalaisen mediakritiikki. Teoksessa Kivikuru, Ullamaija (toim.) Kansa euromyllyssä. Journalismi, kampanjat ja kansalaisten mediamaisemat Suomen EU-jäsenyysprosessissa. Helsinki: Yliopistopaino.

Allern, Elin \& Pedersen, Karina (2007). The Impact of Party Organisational Changes on Democracy. West European Politics 30:1, 68-92.

Aslama, Minna; Kantola, Anu; Kivikuru, Ullamaija \& Valtonen, Sanna (2001). Politics Displaced, Politics Replaced, Elites' and Citizens' Talk on Economic Crises. Teoksessa Kiander, Jaakko; Kalela, Jorma; Kivikuru, Ullamaija; Loikkanen, Heikki \& Simpura, Jussi (toim.) Down from the heavens, Up from the ashes. The Finnish economic crises of the 1990s in the light of economic and social research. VATTjulkaisuja 27:6.

Asp, Kent (2007). Fairness, Informativeness and Scrutiny. The Role of News Media in Democracy. Nordicom Review, Jubilee Issue 2007, 31-49.

Baker, Edwin (2002). Media, Markets and Democracy. Cambridge: Cambridge University Press.

Bengtsson, Åsa \& Mattila, Mikko (2009). Suoran demokratian ja häivedemokratian kannatus Suomessa. Teoksessa Borg, Sami \& Paloheimo, Heikki (toim.). Vaalit yleisödemokratiassa. Tampere: Tampere University Press.

Bennett, W. Lance \& Serrin, William (2005). The Watchdog Role. Teoksessa Overholser, Geneva \& Jamieson, Kathleen Hall (toim.) The Press. Oxford: Oxford University Press.

Bennett, W. Lance; Pickard, Victor; Iozzi, David; Schroeder, Carl; Lagos, Taso \& Caswell, Evans (2004). Managing the Public Sphere: Journalistic Construction of the Great Globalization Debate. Journal of Communication 54:3, 437-455.

Cappella, Joseph \& Jamieson, Kathleen Hall (1997). Spiral of Cynicism. The Press and the Public Good. New York: Oxford University Press.

Cook, Timothy (2005). Section II: The Functions of the Press In a Democracy. Teoksessa Overholser, Geneva \& Jamieson, Kathleen Hall (toim.) The Press. New York: Oxford University Press.

Couldry, Nick; Livingstone, Sonia \& Markham, Tim (2007). Media Consumption and Public Engagement. Beyond the Presumption of Attention. Basingstoke: Palgrave Macmillan.

Curran, James (2005). What Democracy Requires of the Media. Teoksessa Overholser, Geneva \& Jamieson, Kathleen Hall (toim.) The Press. New York: Oxford University Press.

Curran, James (2002). Media and Power. London: Routledge.

Elster, John (1998). Introduction. Teoksessa Elster, John (toim.) Deliberative Democracy. Cambridge: Cambridge University Press. 
Ettema, James (2007). Journalism as Reason-Giving: Deliberative Democracy, Institutional Accountability, and the News Media's Mission. Political Communication 24, 143-16o.

Ferree, Myra Marx; Gamson, William A.; Gerhards, Jürgen \& Rucht, Dieter (2002). Four models of the public sphere in modern democracies. Theory and Society 31, 289-324.

Glasser, Theodore \& Craft, Melanie (1997). Kansalaisjournalismi ja demokraattiset ideaalit. Tiedotustutkimus 20:4, 22-36.

Graber, Doris (2003). The Media and Democracy: Beyond Myths and Stereotypes. Annual Review of Political Science 2003 (6), 139-160.

Grönlund, Kimmo (2006). Osallistuva demokratia. Teoksessa Borg, Sami (toim.) Suomen demokratiaindikaattorit. Oikeusministeriön julkaisuja 2006:1. Helsinki: Oikeusministeriö.

Gunther, Albert \& Liebhart, Janice (2006). Broad Reach or Biased Source? Decomposing the Hostile Media Effect. Journal of Communication 56:3, 449-466.

Habermas, Jurgen (1996). Between Facts and Norms : Contributions to a Discourse Theory of Law and Democracy. Cambridge: Polity Press.

Haikonen, Jyrki \& Kiljunen, Pentti (2003). Mitä mieltä suomalainen? EVAn asennetutkimuksien kertomaa vuosilta 1984-2003. Helsinki: Taloustieto.

Hanberger, Anders (2006). Evaluation of and for Democracy. Evaluation 12:1, 17-37.

Hargreaves, Ian \& Thomas, James (2002). New News, Old News. An ITC and BSC research publication. Verkko-osoite: www.cardiff.ac.uk/jomec/resources/news.pdf

Heikkilä, Heikki (2001). Ohut ja vankka journalismi. Kansalaisuus suomalaisen uutisjournalismin käytännöissä 1990-luvulla. Tampere: Tampereen yliopisto.

Heikkilä, Heikki \& Kunelius, Risto (1997). Julkisen journalismin äärellä. Tiedotustutkimus 20:4, 4-21.

Held, David (2006). Models of Democracy. Third Edition. Stanford University Press, Stanford.

Hemánus, Pertti \& Tervonen, Ilkka (1978). Objektiivinen joukkotiedotus. Helsinki: Otava.

Hibbing, John \& Theiss-Morse, Elizabeth (2002). Stealth Democracy. American's Beliefs About How Government Should Work. Cambridge: Cambridge University Press.

Ho, Shirley \& McLeod, Douglas (2008). Social-Psychological Influences on Opinion Expression in Face-toFace and Computer-Mediated Communication. Communication Research 35:2, 190-207.

Holmberg, Jukka (2004). Etusivun politiikkaa. Yhteiskunnallisten toimijoiden representointi suomalaisissa sanomalehtiuutisissa 1987-2003. Jyväskylä Studies in Humanities 30. Jyväskylä: Jyväskylän yliopisto

Hujanen, Jaana (2009). Kiinnostavaa vai tärkeää? Ihmisläheisen journalismin kaksi polkua. Teoksessa Väliverronen, Esa (toim.) Journalismi murroksessa. Helsinki: Gaudeamus.

Hujanen, Erkki (2007). Lukijakunnan rajamailla. Sanomalehden muuttuvat merkitykset arjessa. Jyväskylä Studies in Humanities 68. Jyväskylä: Jyväskylän yliopisto.

Jääsaari, Johanna \& Savinen, Ari (1995). Television vaalikeskusteluohjelmat yleisön arvioitavina. Tutkimus \& kehitys. Yleisradio, Tutkimus \& kehitys, tutkimusraportti 2/1995. Helsinki: Yleisradio.

Karppinen, Kari; Jääsaari, Johanna \& Kivikuru, Ullamaija (2010). Media ja valta kansalaisten silmin. 2/2010 SSKH - SSKH Reprts and Discussion Papers. Verkko-osoite: http://sockom.helsinki.fi/info/notat/ notat_1002.pdf

Kivikuru, Ullamaija (toim.) (1996). Kansa euromyllyssä. Journalismi, kampanjat ja kansalaisten mediamaisemat Suomen EU-jäsenyysprosessissa. Helsinki: Yliopistopaino.

Koski, Maija (2002). Kun poliitikot pudotettiin jalustalta - kansalaisnäkökulma politiikkaan vuosituhannen vaihteen Suomessa. Teoksessa Kivikuru, Ullamaija (toim.) Laman julkisivut. Media, kansa ja eliitit 1990-luvun talouskriisissä. Helsinki: Palmenia-kustannus.

Kunelius, Risto (2001). Conversation: a Metaphor and a Method for Better Journalism? Journalism Studies 2:1, 31-54.

Kunelius, Risto (2000a). Epistemologisen ahdistuksen tuolle puolen. Epilogi toimittajien ja yleisön journalismipuheeseen. Teoksessa Kunelius, Risto \& Ridell, Seija (toim.) Kaksi katsetta journalismiin. Tiedotusopin laitos, julkaisuja A 94/2000. Tampere: Tampereen yliopisto.

Kunelius, Risto (200ob). Hyvä journalismi? Keskusteluja kiinnostuneiden ja kokeneiden kansalaisten kanssa. Suomen journalistiliitto. Mediakriittinen julkaisusarja 5.

Kärki, Anita (2004). Sivusta seuraten. Sanomalehti lukijoiden kertomuksissa. Jyväskylän yliopisto, SoPhi 83.

Matikainen, Janne (2009). Sosiaalisen ja perinteisen median rajalla. Viestinnän tutkimuskeskus CRC, Helsingin yliopisto. Viestinnän laitoksen tutkimusraportteja 3. 
McNair, Brian (1999). An Introduction to Political Communication. London: Routledge.

McQuail, Denis (1992). Media Performance. Mass Communication and the Public Interest. London: SAGE Publications.

Meyer, Thomas \& Hinchman, Lew (2002). Media Demoracy. How the Media Colonize Politics. Cambridge: Polity Press.

Moring, Tom (2008). Media and Politics in Finland. Teoksessa Strömbäck, Jesper; Ørsten, Mark \& Aalberg, Toril (toim.) Communicating politics: political communication in the nordic countries. Göteborg: Nordicom.

Mouffe, Chantal (1999). Deliberative Democracy or Agonistic Pluralism? Social Research 66:3, 745-758.

Murdock, Graham (2005). Building the Digital Commons. Public Broadcasting in the Age of the Internet. Teoksessa Lowe, Gregory Ferrel \& Jauert, Per (toim.) Cultural Dilemmas in Public Service Broadcasting. Göteborg: Nordicom.

Mäntymäki, Eeva (2006). Hyvinvointivaltio eetterissä. Yleisradion rakentuminen populaarien diskurssien kentillä. Tampere: Tampere University Press.

Napoli, Philip (1999). Deconstructing the Diversity Principle. Journal of Communication 49:4, 7-34.

Nieminen, Hannu (2008). Eurooppalainen julkisuus tutkimuksen kohteena: neljä plus yksi näkökulmaa. Teoksessa Nieminen, Hannu; Karppinen, Kari \& Mörä, Tuomo (toim.) Onko Eurooppa olemassa: näkökulmia eurooppalaiseen julkisuuteen ja demokratiaan. Helsinki: Gaudeamus.

Nieminen, Hannu; Aslama, Minna \& Pantti, Mervi (2005). Media ja demokratia Suomessa. Kriittinen näkökulma. Oikeusministeriön julkaisuja 2005:11. Helsinki: Oikeusministeriö.

Nieminen, Hannu \& Pantti, Mervi (2004). Media markkinoilla. Johdatus joukkoviestintään ja sen tutkimukseen. Helsinki: Loki-kirjat.

Nordenstreng, Kaarle (1996). Katsomosta areenalle. Kansalaisen paluu sananvapauden haltijaksi. Teoksessa Nordenstreng, Kaarle (toim.) Sananvapaus. Helsinki: WSOY.

Norris, Pippa (2000). A Virtuous Circle: Political Communications in Postindustrial Societies. Cambridge: Cambridge University Press.

Pietilä, Veikko (2001). Yleisönosasto ja Internet keskusteluareenoina. Tiedotustutkimus 24:2, 18-33.

Poindexter, Paula; Heider, Don \& McCombs, Maxwell (2006). Watchdog or Good Neighbor? The Public's Expectations of Local News. Press/Politics 11:1, 77-88.

Pulkkinen, Tuija (1996). Snellmanin perintö suomalaisessa sananvapaudessa. Teoksessa Nordenstreng, Kaarle (toim.) Sananvapaus. Helsinki: WsOY.

Rahkonen, Juho (2006). Journalismi taistelukenttänä: Suomen Nato-jäsenyydestä käyty julkinen keskustelu 2003-2004. Tampere: Tampere University Press.

Reunanen, Esa (2003). Budjettijournalismi julkisena keskusteluna. Tekstianalyyttisiä näkökulmia suomalaiseen ja ruotsalaiseen budjettikirjoitteluun. Tampere: Tampere University Press.

Ridell, Seija (2000). Kuuliainen kuluttaja vai kiihkeä kansalainen? Teoksessa Kunelius, Risto \& Ridell, Seija (toim.) Kaksi katsetta journalismiin. Tiedotusopin laitos, julkaisuja A94. Tampere: Tampereen yliopisto.

Ridell, Seija (1998). Tolkullistamisen politiikkaa. Televisiouutisten vastaanotto kriittisestä genrenäkökulmasta. Tampere: Tampereen yliopisto.

Ruoho, liris \& Torkkola, Sinikka (2010). Journalismin sukupuoli. Tampere: Vastapaino.

Ruostetsaari, Ilkka (2003). Valta muutoksessa. Porvoo: WSOY.

Schmitt, Kathleen; Gunther, Albert \& Liebhart, Janice (2004). Why Partisans See Mass Media as Biased. Communication Research 31:6, 623-641.

Schrøder, Kim \& Phillips, Louise (2007). Complexifying Media Power: a Study of the Interplay Between Media and Audience Discourses on Politics. Media Culture Society 29:6, 890-915.

Schrøder, Kim \& Phillips, Louise (2005). The Everyday Construction of Mediated Citizenship. People's Use and Experience of News Media in Denmark. Teoksessa Lowe, Gregory Ferrel \& Jauert, Per (toim.) Cultural Dilemmas in Public Service Broadcasting. Göteborg: Nordicom.

Setälä, Maija (2006). Demokratiakäsite ja demokratian normatiiviset perusteet. Teoksessa Borg, Sami (toim.) Suomen demokratiaindikaattorit. Oikeusministeriön julkaisuja 2006:1. Helsinki: Oikeusministeriö.

Setälä, Maija (2003). Demokratian arvo. Teoriat, käytännöt ja mahdollisuudet. Helsinki: Gaudeamus.

Strandberg, Kim (2008). Public Deliberation Goes On-Line? An Analysis of Citizens Political Discussions on the Internet Prior to the Finnish Parliamentary Elections in 2007. Javnost-The Public 15:1, 71-90. 
Strömbäck, Jesper (2005). In Search of a Standard: Four Models of Democracy and Their Normative Implications for Journalism. Journalism Studies 6:3, 331-345.

Strömbäck, Jesper (2004) Den medialiserade demokratin: om journalistikens idea, verklighet och makt. Stockholm: SNS.

Strömbäck, Jesper (2003). Medierna som fjärde statsmakt - en studie av innebörden av begreppet granskande journalistik. Studier i politisk kommunikation 1. Sundsvall: Demokratiinstitutet.

Strömbäck, Jesper (2001). Gäster hos verkligheten - en studie av journalistik, demokrati och politick misstro. Stockholm/Stehag: Brutus Östlings Bokförlag Symposium.

Trappel, Josef \& Maniglio, Tanja (2008). Do the Media Deliver What Contemporary Democracies Require? The Media for Democracy Monitor (MDM). Paper presented at the Media o8 Communication and Humanity Conference. LSE, Department of Media and Communication. London, September 21st 23rd.

Wahl-Jorgensen, Karin (2008). Disgust, Pleasure and the Failure of the Liberal Democratic Model: Tabloid talk, Media Capital and Emotional Citizenship. International Journal of Media and Cultural Politics 4:2, 145-161.

Zaller, John (2003). A New Standard of News Quality: Burglar Alarms for the Monitorial Citizen. Political Communication 20:2, 109-130.

Zittel, Thomas (2007). Participatory democracy and political participation. Teoksessa Zittel, Thomas \& Fuchs, Dieter (toim.). Participatory democracy and political participation: can participatory engineering bring citizens back in? London: Routledge, 9-27. 